\title{
Working
}

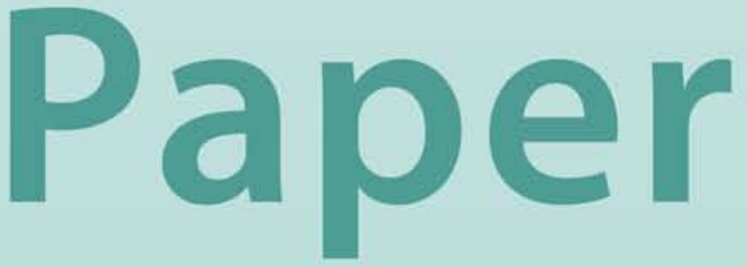


Exchange Rate Pass-Through in the Euro Area: The Role of Asymmetric Pricing Behavior

\author{
Hamid Faruqee
}




\title{
IMF Working Paper
}

European Department

\section{Exchange Rate Pass-Through in the Euro Area: The Role of Asymmetric Pricing Behavior}

\author{
Prepared by Hamid Faruqee ${ }^{1}$ \\ Authorized for distribution by Albert Jaeger
}

January 2004

\begin{abstract}
This Working Paper should not be reported as representing the views of the IMF. The views expressed in this Working Paper are those of the author(s) and do not necessarily represent those of the IMF or IMF policy. Working Papers describe research in progress by the author(s) and are published to elicit comments and to further debate.

Exchange rate pass-through in a set of euro area prices along the pricing chain is examined. Using a vector autoregression (VAR) approach, the empirics analyze the joint time-series behavior of the euro exchange rate and a system of euro-area prices in response to an exchange rate shock. The impulse-response functions from the VAR estimates are used to identify —in a 'new open economy macroeconomics model' - those key behavioral parameters that best replicate the pattern of exchange rate pass-through in the euro area. Area-wide prices are found to display incomplete pass-through, consistent with euro currency-pricing and pricing-to-market behavior. The results are compared to those for the other major industrial economies, and suggest that, as with the United States, "expenditureswitching" effects on the current account still operate but are generally small.

JEL Classification Numbers: F41, F31, E31

Keywords: Exchange Rate Pass-Through, New Open Economy Macroeconomic Models Author's E-Mail Address: HFaruqee@imf.org

\footnotetext{
${ }^{1}$ This paper stems from joint work with Ehsan Choudhri and Dalia Hakura. The author would also like to give special thanks to Susanna Mursula for her outstanding research assistance and thanks to Bankim Chadha, Ehsan Choudhri, Dalia Hakura, Albert Jaeger, and Alessandro Rebucci for helpful discussions and comments. Any remaining errors are the author's.
} 
Contents Page

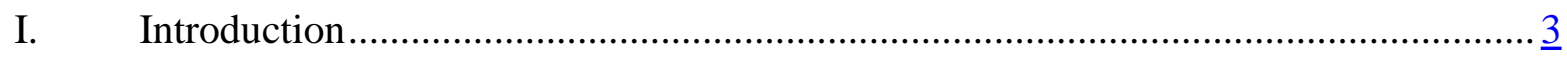

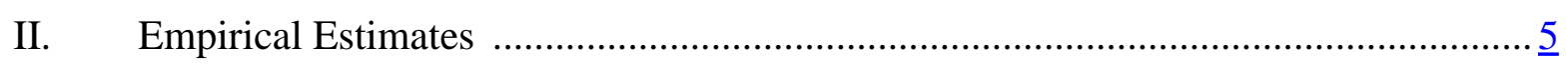

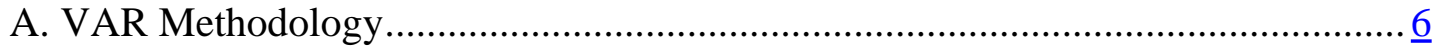

B. Cross-Country Evidence …................................................................

III. Model of Incomplete Pass-Through.............................................................. 11

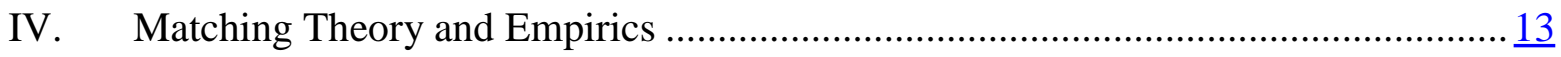

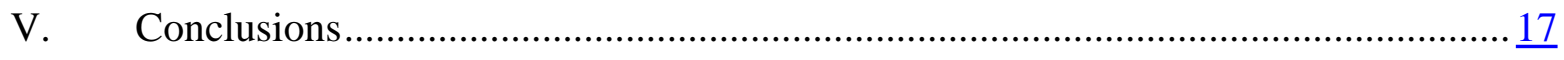

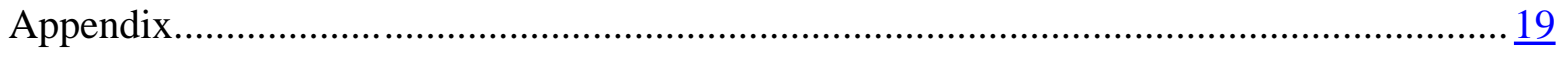

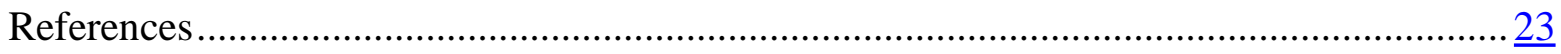

Tables

1. Euro Area Pass-Through Elasticities ................................................................ $\underline{9}$

2. Pass-Through Elasticities in Trade Prices: International Comparisons .................... 11

3. Implicit Estimates of Local Distribution Costs............................................ 16

4. Summary of Behavioral Parameter Estimates ........................................... $\frac{17}{19}$

5. Unit Root and Stationarity Tests ................................................................... $\frac{19}{19}$

6. Cointegration Tests ..................................................................................... $\frac{19}{20}$

7. Bivariate Granger Causality Tests ............................................................

8. Block Exogeneity Tests ........................................................................... 20

9. Euro Area Pass-Through Elasticities Across VAR Re-orderings ............................ $\underline{22}$

Figures

1. Euro Area Nominal Exchange Rates ............................................................ $\underline{3}$

2. Effects of an Exchange Rate Shock on Euro Area Prices......................................... $\underline{8}$

3. Pricing Behavior of Domestic and Foreign Firms ............................................. 14 


\section{INTRODUCTION}

Recent swings in exchange rates and persistent external imbalances, particularly in the United States, have once again focused attention on the global alignment of currencies and current accounts. Over the past two years, the euro has appreciated by 30 percent against the dollar and by 20 percent in effective terms (see Figure 1). Currency movements notwithstanding, the constellation of current account positions still shows considerable imbalances. Namely, the large U.S. current account deficit appears unsustainable from a long-term viewpoint and leaves open the possibility of a further significant decline in the value of the dollar. What role the euro area might play in a global rebalancing scenario, however, remains an open question. $^{2}$
Figure 1.

Euro Area Nominal Exchange Rates

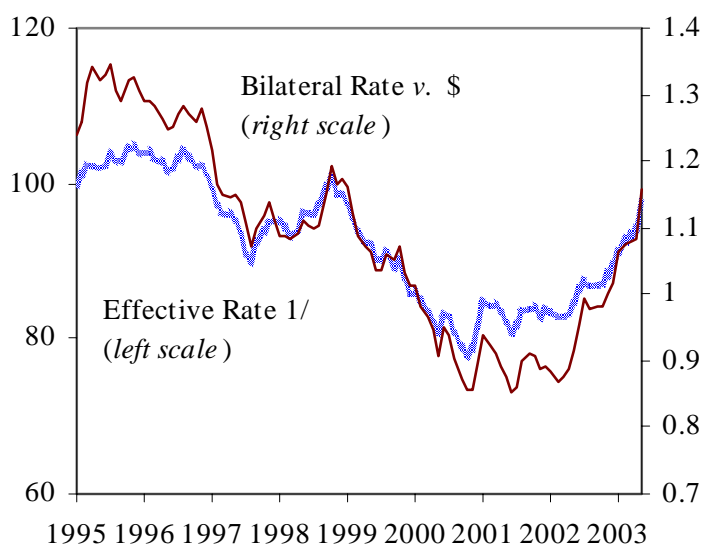

$1 /$ January $1995=100$

A key factor underlying external adjustment is the nature of exchange rate pass-through in the euro area. The behavioral considerations that underlie the extent of pass-through in prices from exchange rate fluctuations and the responsiveness of trade flows to relative price signals are difficult to assess. These issues are important, however, in determining the strength of "expenditure-switching" effects from the exchange rate. ${ }^{3}$ Incomplete pass-through, for example, could delay or diminish the response in external variables and produce a certain degree of "exchange rate disconnect.",

Several economic explanations have been put forth to account for incomplete exchange rate pass-through - a feature that has strong empirical support for a large number of economies, including the euro area. ${ }^{5}$ With nominal rigidity and local currency pricing, destination prices can change very little in the face of exchange rate variation. ${ }^{6}$ With "pricing to market" behavior, segmented markets allow firms to stabilize their destination prices (via changing mark-ups) to preserve foreign market share. In the presence of local distribution costs, firms may also face offsetting factors when the exchange rate changes, leading to international

${ }^{2}$ Interestingly, despite the depreciation of the euro over the period 1995-2001, the euro area current account was not the counterpart to the widening U.S. deficit. See Jaeger (2002).

${ }^{3}$ See Obstfeld (2002) and Engel (2002) for a recent review of these issues.

${ }^{4}$ See Devereux and Engel (2002) and Krugman (1989).

${ }^{5}$ See Goldberg and Knetter (1997) for a survey. See Kieler (2001), Huffner and Schroder (2001), Anderton (2003), and Hahn (2003) for euro area estimates.

${ }^{6}$ See Betts and Devereux (1996, 2000) and Devereux and Engel (2002). 
price discrimination and incomplete pass-through. ${ }^{7}$ These factors can also help account for differential responses between first stage pass-through (e.g., in import prices) and second stage pass-through (e.g., in consumer prices).

This paper examines exchange rate pass-through in the euro area. The methodology proceeds in two parts. First, the empirical analysis follows a vector autoregression (VAR) approach, where the time-series behavior of the euro exchange rate and a system of euro area prices are jointly examined. Specifically, the empirical analysis investigates exchange rate pass-through in a set of prices along the pricing chain. Second, the impulse-response functions (IRFs) from the VAR estimates are used to help calibrate in a new open economy macroeconomics model those key behavioral parameters that underlie the pattern of exchange rate pass-through and external adjustment in the euro area. Repeating the exercise for the United States and the other major industrial countries, the framework can provide some insight into the likely pattern of external adjustment in a multilateral context.

The use of a VAR approach to examine exchange rate pass-through has several advantages compared to single-equation-based methods. Previous studies typically focus on passthrough into a single price (e.g., import or consumer prices), without further distinguishing the types of underlying exchange rate shocks (e.g., permanent or transitory). By investigating exchange rate pass-through into a set of prices along the pricing chain, the VAR analysis characterizes not only absolute but relative pass-through in upstream and downstream prices. Second, the VAR methodology potentially allows one to identify specific "structural" shocks affecting the system. In this case, a structural exchange rate shock is identified through a Cholesky decomposition of innovations, where exchange rate fluctuations at higher frequencies are assumed to be largely driven by exogenous asset market disturbances.

Using this identification scheme, one can map the empirical results into a well-defined shock in an economic model of incomplete pass-through. Specifically, the estimated impulseresponse functions from an exchange rate shock in the VAR are matched to the response patterns generated by the corresponding asset market disturbance in the pass-through model. Minimizing the distance between these sets of IRFs is used to identify key behavioral parameters that underlie the pattern of exchange rate pass-through. These parameters include the pricing behavior of firms (i.e., the extent of local currency pricing), the degree of nominal rigidity, and the extent of local distribution and trading costs generating international price discrimination.

Based on the empirical estimates, the analysis investigates the expected impact of the recent euro appreciation on area-wide prices and trade flows. Combined with the calibrated model, the scenario of a further decline in the value of the dollar and the resultant pattern of external adjustment is also examined. In particular, for a uniform decline in the dollar, the pattern of realignment in external positions between the euro area and the other major industrial economies is further analyzed.

${ }^{7}$ See Corsetti and Dedola (2002) and Choudhri, Faruqee, and Hakura (2002). 


\section{EMPIRICAL ESTIMATES}

The empirical analysis focuses on euro area prices and the exchange rate at a monthly frequency. The time span covers the period from 1990 through 2002. All series are expressed in logarithms. For the euro exchange rate $s$, the nominal effective series is defined for the ECB's "narrow" group of partner countries or areas. ${ }^{8}$ For factor prices or wage earnings $w$, the series derive from quarterly data on nominal compensation per employee, extrapolated to a monthly frequency. ${ }^{9}$ For trade prices, import prices $p m$ and export prices $p x$ are based on unit values in extra-area manufacturing trade. ${ }^{10}$ Producer prices $p y$ are based on the producer price index for manufacturing, excluding construction and energy. Consumer prices $p c$ are based on the core CPI-i.e., excluding energy and unprocessed foods-from the harmonized index of consumer prices (HICP). ${ }^{11}$ The exclusion of energy prices is motivated by the standard finding that its pass-through behavior differs from that of other goods. ${ }^{12}$ The use of extra-area trade data helps avoid potential pitfalls from ascertaining pass-through for the euro area from estimates for individual member countries. To the extent that intra-area trade systematically differs from extra-area trade with respect to pass-through behavior, aggregating individual country estimates to generate an area-wide measure could suffer from a "fallacy of composition." Hufner and Schroder (2001), for example, construct pass-through estimates for euro area consumer prices by summing over individual country estimates, based on each country's weight in the area-wide HICP. The analysis is then required to make some "correction" of the estimates due to the presence of intra-area trade.

Before turning to the VAR estimation of euro area pass-through, some preliminary tests of the data were first conducted. Namely, unit root and stationarity tests indicate that these nominal variables are nonstationary in levels but stationary in first differences, suggesting that they are integrated of order one or $I(1)$ series. ${ }^{13}$ Furthermore, residual-based

${ }^{8}$ Partner countries or areas consist of the United States, Japan, Switzerland, the United Kingdom, Sweden, Denmark, Norway, Canada, Australia, Hong Kong (SAR), Korea, and Singapore.

${ }^{9}$ Price and wage data are from Eurostat and not seasonally adjusted. The area-wide measures reflect aggregates of the 11 participating countries through December 2000. Thereafter, the chained series include Greece as the $12^{\text {th }}$ member country.

${ }^{10}$ Manufactured goods include Sections 5 to 8 of the Standard International Trade Classification (SITC).

${ }^{11}$ For the United States, Japan, the United Kingdom, and Canada, all corresponding monthly series were drawn from the IMF's International Financial Statistics, except wages which were obtained from the OECD's Analytical Database.

${ }^{12}$ See, for example, Campa and Goldberg (2001).

${ }^{13}$ The differenced series for euro area consumer and import prices were borderline nonstationary; see the appendix. But as is well known, unit root and stationarity tests have low 
cointegration tests do not find evidence of cointegration among the variables; see the appendix. Given potential nonstationarity and lack of cointegration in the levels data, estimating the VAR in first differences is appropriate.

\section{A. VAR Methodology}

The VAR approach examines the joint historical time-series behavior of the euro exchange rate and a system of euro area prices. Specifically, the reduced-form $\operatorname{VAR}(p)$ can be written a follows:

$$
\begin{aligned}
& Y_{t}=c+A(L) Y_{t-1}+\mu_{\mathrm{t}} ; \\
& \mathrm{E}\left[\mu_{\mathrm{t}} \mu_{\mathrm{t}}^{\prime}\right]=\Omega,
\end{aligned}
$$

where $Y=\left[\begin{array}{lllll}\Delta s & \Delta w & \Delta p m \Delta p x & \Delta p y & \Delta p c\end{array}\right]^{\prime}, c$ is a vector of deterministic terms (i.e., monthly time dummies), $A$ is a matrix polynomial of degree of $p$ in the lag operator $L$, and $\mu$ is the (6x1) vector of reduced-form residuals with variance-covariance matrix $\Omega$. The exchange rate is placed first in the order of variables, reflecting the presumption that exchange rate innovations at monthly frequency are primarily driven by exogenous asset market disturbances. ${ }^{14}$ For prices, the ordering after the exchange rate is motivated by the pricing chain, from factor input prices to trade prices to wholesale producer prices and retail consumer prices. The ordering among price variables after the exchange rate does not matter for the subsequent analysis of the exchange rate shock.

To recover the underlying exchange rate shock, the Cholesky decomposition of the matrix $\Omega$ is used to produce orthogonalized innovations $\varepsilon$. These disturbance terms are expressed in terms of the reduced-form VAR innovations as follows:

$$
C \varepsilon_{t}=\mu_{t},
$$

where $C$ is the unique lower triangular Cholesky matrix with 1s along its principal diagonal. ${ }^{15}$ Because the exchange rate appears first in the VAR, the recursive structure in (2) imposes the assumption that orthogonalized innovations to the exchange rate depend only on the residuals from the exchange rate equation and not the other variables. This identification

power, making it difficult to distinguish between stationary and unit root processes in finite samples.

14 The identification scheme largely follows Choudhri, Faruqee, and Hakura (2002). That analysis also includes the interest rate in the VAR in order to further distinguish between the effects of interest rate and exchange rate shocks on prices. McCarthy (2001) and Hahn (2003) also uses a Cholesky decomposition to examine pass-through based on a somewhat different model.

15 The symmetric positive definite matrix $\Omega$ can be decomposed into unique lower triangular and diagonal matrices such that $\Omega=C D C^{\prime}$. Using equation (2), this decomposition then produces innovation terms that are uncorrelated by construction-i.e., $\mathrm{E}\left[\varepsilon_{\mathrm{t}} \varepsilon_{\mathrm{t}}^{\prime}\right]=D$. 
thus allows for a simple correspondence between the VAR estimates and a well-defined shock in the model described later. For prices, the corresponding disturbance term will represent a mix of shocks, including the structural exchange rate shock. ${ }^{16}$

An alternative identification scheme would place the exchange rate last (or near last) in the VAR. This ordering is motivated by the view that prices (and quantities) are predetermined in the very short run and, thus, cannot respond to an exchange rate shock, whereas the exchange rate can respond to various shocks. ${ }^{17}$ While this restriction may indeed be valid for many prices, it may not be appropriate for others. More to point, this ordering imposes a specific pass-through pattern in the estimates, and, ultimately, certain behavioral features in the model, that the current analysis seeks to investigate.

The implications of the present identifying restriction can be further understood from the structural representation of the VAR:

$$
F(L) Y_{t}=k+\varepsilon_{\mathrm{t}}
$$

where $F(L)$ is a matrix polynomial of degree $p+1, k$ is a transformation of deterministic terms (i.e., $C k=c$ ), and $\varepsilon$ is the vector of structural shocks. One can show that the identification scheme based on the Cholesky decomposition introduces the following restriction: in the first equation-i.e., for the exchange rate $\Delta s$, the coefficients on contemporaneous price changes $\Delta w, \Delta p m, \Delta p x, \Delta p y$, and $\Delta p c$ are equal to zero.

The economic justification for this identifying assumption can be understood as follows. Exchange rates, especially at high frequencies, are essentially driven by asset market rather than goods market disturbances. From the well-known "asset market view" of exchange rate determination, the prevailing exchange rate as a forward-looking price should reflect not only current but expected future economic conditions affecting the supply and demand for foreign exchange. Changes in the exchange rate can then be expressed in terms of a predictable component (usually deemed to be small) and a potentially large unexpected component, reflecting the impact of new information on expectations of all future economic conditions. ${ }^{18}$ Short-run changes in the exchange rate, consequently, are likely to be dominated by "news" and not be predictable based on lagged price data. ${ }^{19}$ The VAR identification scheme takes

\footnotetext{
${ }^{16}$ For the first variable-i.e., the exchange rate, the orthogonalized disturbance term is given by $\varepsilon_{1 t}=\mu_{1 t}$. For the $j$ th variable $(j>1)$ in the VAR, the corresponding shock term is given by $\varepsilon_{j t}=\mu_{j t}-c_{j, 1} \varepsilon_{j t} \ldots-c_{j, j-1} \varepsilon_{j t}$, where $c_{j, i}$ correspond to the entries of the Cholesky matrix; See Hamilton (1994).

${ }^{17}$ See, for example, Peersman and Smets (2002).

${ }^{18}$ See Mussa (1984).

${ }^{19}$ Granger causality and block exogeneity tests find that (lagged) euro area prices have no predictive value for the euro exchange rate. The exchange rate, however, helps predict (at
} 
this view one step further, specifying that contemporaneous price innovations also do not help explain exchange rate innovations. ${ }^{20}$

Based on the reduced-form estimates of the VAR and the Cholesky decomposition to identify structural shocks, accumulated impulse-response functions to a unit structural exchange rate shock are shown in Figure 2. ${ }^{21}$ The horizontal axis measures the time horizon in terms of months after the shock; the vertical axis measures the percent deviation in prices from their baseline levels.

Figure 2. Effects of an Exchange Rate Shock on Euro Area Prices (unit structural shock; estimation period: 1990-2002)

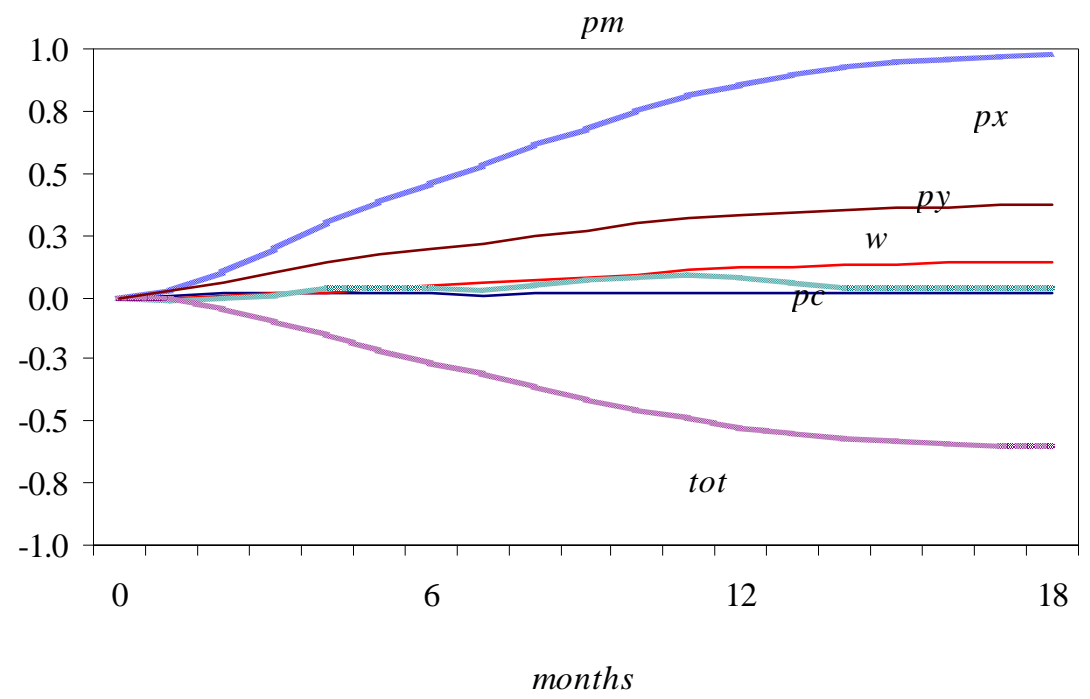

Figure 2 shows that the short-run effects of an exchange rate shock on prices are very small in the euro area. Prices tend to be predetermined or very sticky (in local currency) initially in response to a unit depreciation in the euro effective exchange rate. Over time, the degree of exchange rate pass-through generally tends to rise, although the extent in factor and retail prices remains comparatively small. Wholesale producer prices tend to rise more than retail consumer prices, but the greatest response is in trade prices. A year to 18 months after the

least) trade prices. See the appendix. Restricted VAR estimates (not reported) excluding lagged prices from the exchange rate equation yield very similar results.

${ }^{20}$ Reporting lags in prices may be one motivating factor. The presence of noise traders may be another relevant consideration. See, for example, Jeanne and Rose (2002) and Devereux and Engel (2002).

${ }^{21}$ Given the large number of parameters in the VAR, a parsimonious lag structure is sought. The lag length $p$ is chosen by starting with a maximum lag length and sequentially testing the incremental significance of dropping an additional lag based on the likelihood ratio test. 
shock, export prices respond by almost half the response in import prices, which moves in proportion to the unit exchange rate shock, suggesting full pass-through. Consequently, the manufacturing terms of trade (tot) for the euro area tends to worsen or decline in response to an exchange rate depreciation. ${ }^{22}$

Normalizing the price responses in Figure 2 by the exchange rate response, Table 1 summarizes the time paths for pass-through elasticities in euro area prices. After 18 months, pass-through rates in export and import prices are about one-half and one, respectively. Wage pass-through is relatively very small at 5 percent. Pass-through in wholesale prices is nearly 20 percent, significantly exceeding the pass-through in retail prices. ${ }^{23}$ These results are robust to reorderings of the VAR; see the appendix. Using headline rather than core inflation (or including longer lags), would raise the degree of pass-through in consumer prices to near 10 percent at 18 months, but the pattern of relative pass-through remains intact.

Table 1. Euro Area Pass-Through Elasticities (Percent change in prices divided by percent change in exchange rate)

\begin{tabular}{lcccc}
\hline & $T=1$ & $t=6$ & $t=12$ & $t=18$ \\
\hline Cpi & 0.00 & 0.01 & 0.02 & 0.02 \\
Ppi & 0.00 & 0.04 & 0.11 & 0.17 \\
Wage & -0.02 & 0.04 & 0.07 & 0.05 \\
Px & 0.02 & 0.18 & 0.31 & 0.45 \\
Pm & 0.03 & 0.42 & 0.81 & 1.17 \\
\hline
\end{tabular}

Notes: Based on impulse-response functions from 6-variable VAR estimated on monthly data from 1990 through 2002.

Full pass-through in euro area import prices over time may be a somewhat surprising result. ${ }^{24}$ Alternative specifications-e.g., with coefficient restrictions or VAR reorderings- tend to yield smaller but still high pass-through elasticities between 0.7 and 1 . In a recent paper that also examines extra-area manufacturing trade prices, Anderton (2003) also finds generally

22 Obstfeld and Rogoff (2000a) provide extensive evidence that the terms of trade declines with a currency depreciation-an observation that appears at odds with the implications of strict LCP models. See also Lane (2001) for a review.

${ }^{23}$ Gagnon and Ihrig (2002) find very low degrees of pass-through in consumer prices for twenty industrial countries and argue that pass-through has been declining. Their average estimate for long-run CPI pass-through is around 5 percent.

${ }^{24}$ These estimates should be taken as indicative, with sizable the standard errors. Based on boot-strapped standard errors, the 90 percent confidence interval for import prices is the widest, suggesting pass-through at 18 months in the range $(0.6,1.4)$. The median value of this band suggest a slightly lower degree of import price pass-through (i.e., 0.95 at 18 months); otherwise, the median and estimated impulse-responses responses closely coincide. 
high (albeit not full) pass-through between 0.5 to 0.7 , based on a single equation approach. ${ }^{25}$ Given the identification of near-permanent exchange rate shocks from the VAR estimates here, it is not surprising that import price pass-through in this analysis lies somewhat above those single-equation based estimates.

\section{B. Cross-Country Evidence}

Before relating the empirical findings to the theoretical model, it is useful to compare the pass-through results for the euro area to the other major industrial economies. Repeating the VAR exercise for the United States, Japan, the United Kingdom, and Canada produces the pass-through coefficients for trade prices shown in Table 2.

As evident from the table, pass-through is incomplete, particularly in the short run. For the United States, pass-through in trade prices at the time of the shock is near zero, quite similar to the response of euro area. But while pass-through rises significantly over time in the euro area, the extent of the increase is much smaller for the United States. For the other countries, pass-through to import and export prices are higher on impact than for the United States and the euro area. For Canada and Japan, import prices pass-through estimates are about 60 to 70 percent initially and remain around those levels over time; for the United Kingdom import price pass-through eventually reaches 60 percent, but is initially half that. Pass-through in export prices is (eventually) around 50 percent for these three countries, similar to the euro area.

${ }^{25}$ The time pattern is similar, though, with most of the price adjustment transpiring by 5 quarters. Based on a quarterly VAR, Hahn (2003) reports similar findings on the degree using the euro area non-oil import deflator. 
Table 2. Pass-Through Elasticities in Trade Prices: International Comparisons

\begin{tabular}{lllcc}
\hline & $t=1$ & $t=6$ & $t=12$ & $t=18$ \\
\hline Euro Area & 0.03 & \multicolumn{3}{c}{ Import Prices } \\
United States & 0.06 & 0.42 & 0.81 & 1.17 \\
Japan & 0.61 & 0.56 & 0.18 & 0.30 \\
United Kingdom & 0.28 & 0.58 & 0.57 & 0.57 \\
Canada & 0.68 & 0.54 & 0.57 & 0.60 \\
& \multicolumn{4}{c}{ Export Prices } \\
Euro Area & 0.02 & 0.18 & 0.62 & 0.68 \\
United States & 0.00 & 0.00 & 0.06 & 0.45 \\
Japan & 0.62 & 0.50 & 0.48 & 0.12 \\
United Kingdom & 0.16 & 0.47 & 0.46 & 0.47 \\
Canada & 0.35 & 0.19 & 0.35 & 0.50 \\
\hline
\end{tabular}

Notes: Based on impulse-response functions from 6-variable VAR estimated from 1990 through 2002. For the euro area, import and export prices based on unit values in manufacturing trade. For others, import and export prices based on unit values in total trade.

\section{Model of InComplete Pass-Through}

This section briefly describes the analytical framework used to interpret the VAR evidence in terms of underlying economic behavior. The stylized model draws from many of the common themes found in the "new open economy macroeconomics" (NOEM) paradigm, following the seminal work of Obstfeld and Rogoff (1995). ${ }^{26}$ A detailed derivation of the micro-founded model employed here can be found in Choudhri, Faruqee, and Hakura (2002). A descriptive summary of the incomplete pass-through model is as follows.

Imperfect competition characterizes the production and allocation of two differentiated goods - a traded intermediate good and a nontraded final (consumption) good. One differentiated primary factor (labor) enters the production of traded goods. A domestic retail sector also relying on labor services is then needed to transform intermediate goods into final consumption goods in each country. This structure gives rise to a pricing chain with five price indices: retail consumer prices, wholesale producer prices, import and export prices, and wages or factor prices.

Prices and wages are not fully flexible. Instead, prices and wages are updated only infrequently based on Calvo-type adjustment. ${ }^{27}$ Specifically, the probability that a firm will

\footnotetext{
${ }^{26}$ See Lane (2001) for a survey of this literature.

${ }^{27}$ See Calvo (1983). See Kollman (2001) for a NOEM analysis with sticky wages and prices but without distribution costs.
} 
revise its price in a given period is fixed equal to $\pi$. Correspondingly, the average time interval over which prices remain fixed is $(1-\pi) / \pi .^{28}$ This framework generates staggered price setting behavior in the economy.

With nominal rigidity in an open economy, the question arises as to whether prices are sticky in terms of domestic or foreign currency. The two cases are referred to as local currency pricing (LCP), where prices are rigid in term of the destination or buyer's currency, and producer currency pricing (PCP), where prices are rigid in terms of the originating or seller's currency. Both types of pricing behavior are allowed for in the model. Specifically, the parameters $\phi$ and $\phi^{*}$ denote the share of domestic and foreign firms following producer currency pricing behavior. If $\phi=1$, all domestic firms engage in PCP; If $\phi=0$, all domestic firms engage in LCP.

Finally, segmented goods markets allow firms to price discriminate internationally. Following Corsetti and Dedola (2002), firms face trading or distribution costs in the export market, providing an incentive for 'pricing to market' (PTM) given their ability to do so. ${ }^{29}$ Specifically, imports are assumed to go through local distribution channels before they can be used in the production of either intermediate or final goods. To sell one unit in the export market requires $\delta$ units of local labor services. ${ }^{30}$ With this dependence on local currency wages, changes in the exchange rate lead to incomplete pass-through in trade prices and "pricing to market" behavior described by Krugman (1987) through a cost or supply mechanism. ${ }^{31}$ The introduction of "pricing to market" along these lines helps limit the effects of import price pass-through on retail prices and helps generate greater overall persistence in the degree of incomplete pass-through over time.

Benchmarks for fixed parameters in the model generally follow the calibration in Choudhri, Faruqee and Hakura (2002) which are generally based on average estimated values for the

${ }^{28}$ Choudhri, Faruqee, and Hakura (2002) also examine the cases of wage and/or price flexibility (i.e., $\pi=1$ ) and find that these model variants generally fall short in explaining the empirical impulse-responses.

${ }^{29}$ Investigating extra-area import prices, Anderton (2003) finds that foreign suppliers attach a significant weight on the PTM strategy in efforts to maintain market share. Herzberg et al. (2003) find PTM to be the dominant consideration for U.K. import prices. Kieler (2001) provides comparative estimates for several industrial countries.

${ }^{30}$ Burstein, Neves and Rebelo (2001) find that distribution costs account for roughly 40 percent of final consumer prices in the United States. For comparison purposes in what follows, the distribution cost parameter $\delta$ is recast in similar units.

${ }^{31}$ See also Kasa (1992) and Faruqee (1995) for analyses that introduce market-specific costs as a way to generate incomplete pass-through and pricing-to-market behavior. An alternative approach focuses on varying mark-ups and demand elasticities through translog (i.e., nonCES) preferences can be found in Bergin and Feenstra (2001). 
major industrial countries_-including euro area members Germany, France and Italy. Monetary policy, for example, is specified by an interest rate rule targeting expected inflation in consumer prices and allowing for interest rate smoothing, with the corresponding parameter weights based on the average estimates for the (non-U.S.) G-7 countries.

\section{MATChING TheORY AND EMPIRICS}

To match the empirical impulse-response patterns, an asset market shock $\xi$ to uncovered interest rate parity (UIP) in the model is considered. ${ }^{32}$ The scale and persistence of $\xi$ is calibrated to replicate the VAR's accumulated impulse-response path for the exchange rate from a structural exchange rate shock $\varepsilon_{s}$. Simulating the model's price responses to the UIP shock then generates the analytical impulse-response functions. To find the "optimal" structural parameter values in the model consistent with the empirical evidence, the following loss function is minimized: ${ }^{33}$

$$
\min _{\{\theta\}}\left[\operatorname{IR}(P, \xi ; \theta)-\operatorname{IR}^{V A R}\left(P, \varepsilon_{s}\right)\right]^{\prime}\left[\operatorname{IR}(P, \xi ; \theta)-I^{V A R}\left(P, \varepsilon_{s}\right)\right]
$$

where $I R(P, \xi ; \theta)$ denotes the vector of simulated impulse-responses for the price vector $P$ from an $\xi$ shock in the model conditional on the set of structural parameters $\theta=\left\{\phi, \phi^{*}, \pi, \delta\right\} .^{34} I R^{V A R}\left(P, \varepsilon_{s}\right)$ denotes the vector of accumulated impulse-responses to a structural exchange rate shock $\varepsilon_{s}$ in the VAR. The time horizon for the impulse-response paths is 18 months.

Figure 3 displays the combinations of LCP and PCP behavior in domestic and foreign firms that best replicate the price responses--particularly, for trade prices--derived from the VAR estimates for each of the major industrial economies. The vertical axis measures the extent of PCP behavior $\phi^{*}$ in foreign firms (i.e., producing home imports) and the horizontal axis measures the extent of PCP behavior $\phi$ in domestic firms (i.e., producing home exports).

\footnotetext{
${ }^{32}$ The UIP shock can be interpreted in terms of a stochastic bias term in foreign exchange market expectations. See Choudhri, Faruqee, and Hakura (2002).

33 The standard errors for the impulse-response trajectories are fairly similar, suggesting that minimizing the (unweighted) least squares should yield similar parameters as the weighted least squares calculation following Smets and Wouters (2002). The weighted approach would give less weight to import prices in favor of consumer prices.

34 The elasticity of substitution $\sigma$ between traded goods, broadly defined, was also chosen to minimize the distance between IRFs and found to be fairly low $(\sigma=2)$, in line with Choudhri, Faruqee and Hakura (2002), Smets and Wouters (2002) and the references cited therein. The elasticity of substitution $\theta$ between specific varieties was also allowed to vary within a range $(\theta=4$ to 10$)$ consistent with plausible markups.
} 
In the figure, the origin represents local currency pricing at home and abroad, while the opposing corner represents the case of universal producer currency pricing. The 45-degree line connecting them reflects symmetric combinations of local and producer currency pricing. In terms of symmetric outcomes, the mid-point along the 45-degree line tends to outperform either extreme empirically as shown by Choudhri, Faruqee and Hakura (2002). The intuition is as follows. Exclusive reliance on LCP behavior in both countries produces stable import prices at the destination, which generally squares well with the data, at the expense of unstable export prices at the point of origin, which does not. The reverse is true in the case of PCP. As is evident from the VAR results in Table 2, both export and import prices in a given currency show incomplete pass-through. Consequently, a mix of the two behaviors fares better.

Figure 3. Pricing Behavior of Domestic

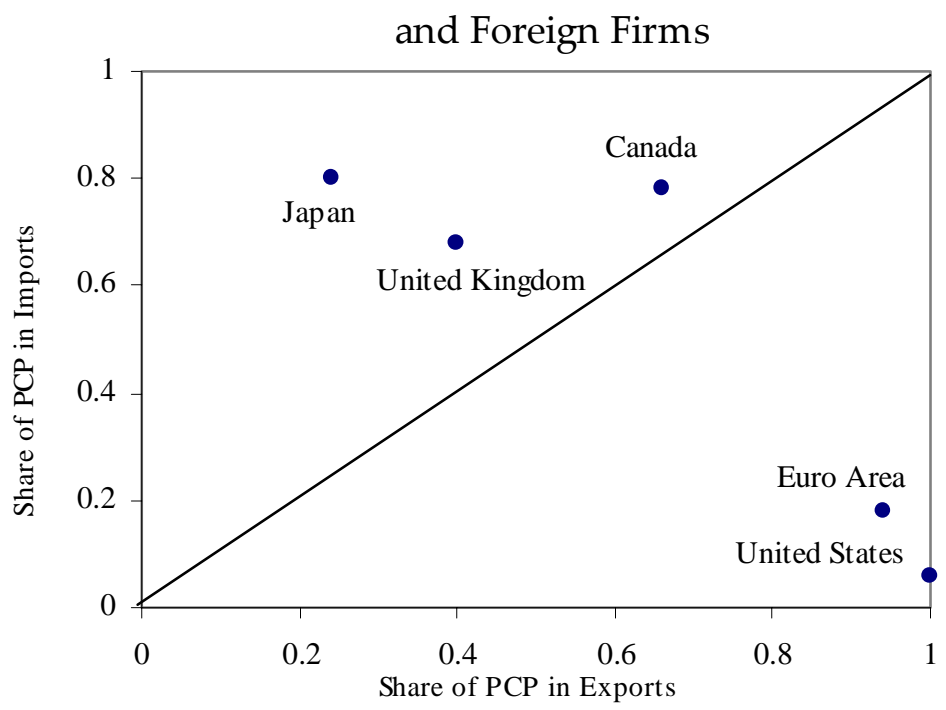

Figure 3 indicates, though, that the opposing diagonal is more relevant empirically in describing the pricing behavior of traded goods. Specifically, asymmetric pricing behavior between domestic and foreign firms appears more consistent with the data. Allowing for LCP to a greater degree in certain trade prices and PCP to a greater extent in other trade prices tends to be more consistent than equal degrees of each. Specifically, the smaller, more open economies and Japan gravitate toward pricing in foreign currencies-i.e., LCP in exports and PCP in imports, while the larger, more insular economies of the United States and the euro area gravitate toward pricing in domestic currencies-i.e., LCP in imports and PCP in exports. As further supporting evidence, the implicit currency pricing behavior suggested by Figure 3 appear very consistent with the data on invoice currencies for these countries. ${ }^{35}$

\footnotetext{
${ }^{35}$ Bekx (1998) reports the following 1995 shares of import and export prices that are respectively invoiced in domestic currency (figures in percent): United States (81,92), Japan $(23,36)$, United Kingdom $(43,62)$, and Germany $(52,75)$. Note that the percentages for Germany refer to deutsche mark rather than all euro-area currencies.
} 
For the United Kingdom, pricing behavior is consistent with an "outward orientation." Domestic firms exporting to foreign markets tend toward LCP and set and stabilize prices in terms of foreign or destination currencies, safeguarding export market share. Import prices also tend to be rigid in terms of foreign currencies, as foreign exporting firms are less sensitive to fluctuations in their destination currency prices. Canada is similar to the United Kingdom with foreign currencies playing a large role in price-setting behavior of traded goods, albeit closer to the symmetric or equal weighting case.

Despite its relative economic size, Japan also exhibits considerable outward orientation. From Table 2, recall that both Japanese import and export prices show considerable passthrough on impact akin to the smaller, more open economies considered here. These results suggest that Japanese exporting firms predominantly engage in local currency pricing, while foreign firms largely engage in producer currency pricing. This finding accords with the conventional wisdom regarding the behavior of Japanese and foreign (predominantly U.S.) exporting firms described in Giovannini (1988), Marston (1990) and others. ${ }^{36}$

For the larger, more insular economies excluding Japan, both domestic and foreign firms tend to price in the 'dominant' currency associated with the large economy. For foreign firms exporting to the United States and the euro area, this translates into destination currency pricing in dollars and euros, respectively. For U.S. and euro area firms exporting abroad, this translates into producer or domestic currency pricing. For the United States, this result is well established.

The similarity between the United States and the euro area is somewhat striking. While it is generally accepted that U.S. firms exporting to the euro area (and elsewhere) primarily invoice in dollars and engage in dollar-currency pricing, less is known about the pricing behavior of euro area firms. ${ }^{37}$ The results here suggest that the euro area behaves in some measure like the United States with respect to the predominant role of domestic currency pricing for international transactions. The finding is largely driven by the similar lack of pass-through on impact of U.S. and area-wide import and export prices shown in Table 2. The use of manufacturing trade prices for the euro area accentuates this similarity; although using total extra-area trade prices (which show higher pass-through) would only slightly alter the relative placements shown in Figure 3.

There are also some important differences worth highlighting between the United States and the euro area. Specifically, the dynamic response of prices suggests significantly higher passthrough (particularly in import prices) for the euro area over time. Interestingly, this translates into a higher estimate for the Calvo parameter $\pi-$ i.e., reflecting greater nominal

\footnotetext{
${ }^{36}$ See Dominguez (1999) for a related discussion of the limited role of the yen as an international currency, particularly as an invoicing currency.

${ }^{37}$ Some have suggested that the international role of euro will expand over time. See Bekx (1998) and Devereux, Engel and Tille (1999).
} 
flexibility. ${ }^{38}$ Imposing a similar $\pi$ value would shift the euro area in Figure 3 toward the other countries and away from the United States in terms of the mix of LCP versus PCP firms, although it would remain more closely aligned with United States.

In all countries, exchange rate pass-through in consumer prices is significantly lower than in import prices. In the model, this "wedge" between intermediate and final goods is represented by local distribution, marketing, or trading costs. Consequently, implicit estimates of these costs are fairly substantial. ${ }^{39}$ Adding nontraded intermediate goods directly into the production of final goods would lower the reliance on nontraded distribution costs. Illustrative country estimates of distribution costs--measured as a share of the final goods price--are shown in Table 3. The estimates are expressed as broad ranges, reflecting the fact that certain combinations of distribution costs and the degree of nominal rigidity produced similar fits of the model. The overall range spans 45 percent for the United States up to 70 percent for Japan. ${ }^{40}$ Burstein, Neves, and Rebelo (2001) estimate a 40 percent share for distribution costs in the United States.

Table 3. Implicit Estimates of Local Distribution Costs (In percent of final goods price)

\begin{tabular}{ccccc}
\hline United States & Euro Area & Japan & United Kingdom & Canada \\
\hline $45-65$ & $55-65$ & $65-70$ & $60-65$ & $50-65$
\end{tabular}

Notes: Estimates based on minimum distance between calibrated model and country VAR impulse response functions for alternative degrees of price rigidity.

Table 4 reports a summary of the "optimized" structural parameters that minimize the distance between the impulse-response functions from the model and each country's VAR. The table also provides an " $R$-squared" value, based on the minimized loss or sum of squared deviations between model and VAR, normalized by the total sum of squares for prices from the VAR impulse-response trajectories. The "fit" of the pass-through model is generally very good overall, albeit less so for the United States.

\footnotetext{
${ }^{38}$ The estimates for $\pi$ typically range from 5 percent to 10 percent, suggesting an average duration between price changes of 3-6 quarters. The $\pi$ estimates for the euro area (United States) are at the higher (lower) end of this range, suggesting shorter (longer) durations between price changes.

${ }^{39}$ Adding nontraded intermediate goods directly into the production of final goods would lower the reliance on distribution costs to drive the wedge between import and consumer prices. See, for example, Hunt and Rebucci (2003).

${ }^{40}$ High estimates of implicit distribution costs in Japan may reflect aspects of its unique distribution system. See Flath (2003).
} 
Table 4. Summary of Behavioral Parameter Estimates

\begin{tabular}{cccccc}
\hline & United States & Euro Area & Japan & United Kingdom & Canada \\
\hline & & & & & \\
$\phi$ & 1.00 & 0.94 & 0.24 & 0.40 & 0.66 \\
$\phi^{*}$ & 0.04 & 0.18 & 0.80 & 0.68 & 0.78 \\
$\pi$ & 0.05 & 0.10 & 0.05 & 0.05 & 0.10 \\
$\delta$ & 0.65 & 0.60 & 0.65 & 0.65 & 0.60 \\
& & & & & \\
$R^{2}$ & 0.61 & 0.91 & 0.98 & 0.91 & 0.88 \\
\hline
\end{tabular}

Notes: Optimized values based on minimum distance between calibrated model and country VAR impulse response functions. $R$-squared based on sum of squared deviations between model and VAR impulse-responses normalized by total sum of squares from VAR impulse-responses.

The estimates for $\phi$ and $\phi *$ tend to be pinned down fairly well or precisely by the shorter-run pass-through behavior in the empirical impulse-response patterns. For $\delta$ and $\pi$, several combinations of parameter values in the model yield similar fits to the data. Both affect the degree of persistence in prices and wages. Consequently, higher values of $\delta$ or lower values of $\pi$ can both generate protracted, incomplete pass-through over time where relevant.

Local currency pricing and "pricing to market" behavior notwithstanding, expenditure switching effects still operate in these economies, although short-run trade elasticities may be small. ${ }^{41}$ Based on the calibrated model, an exchange rate depreciation can be shown to improve the trade balance overall, once both volume and pass-through effects are factored in. ${ }^{42}$ Given its generally small effects on the trade balance, however, the exchange rate adjustment required to achieve a moderate degree of external adjustment may be substantial in the absence of adjustment in other variables.

\section{Conclusions}

Incomplete exchange rate pass-through in prices is a well-documented empirical regularity for many economies, including the euro area. A better understanding of the economic behavior underlying limited pass-through is an important consideration for investigating the

${ }^{41}$ The classic Marshall-Lerner-Robinson (MLR) condition requires that the sum of trade elasticities exceed unity for a depreciation to improve the trade balance under traditional pass-through assumptions (i.e., zero and full pass-through in export and import prices, respectively). For example, Isard et al. (2001) use elasticity benchmarks of 0.7 and 0.9 for export and import volumes. When pass-through is incomplete, however, the MLR requirement need not apply.

${ }^{42}$ Using calibrated model described here, Faruqee (2003) examines the trade impact of a uniform dollar decline on the external positions of the major industrial economies. 
implications of currency movements. The analysis here has sought to examine pass-through in a set of euro area prices along the pricing chain by using a VAR approach to identify the effects of an exogenous exchange rate shock. Mapping the effects of this structural shock into an analytical framework helps identify behavioral features that could help account for the nature of incomplete pass-through in the euro area. On the basis of the analysis, the following conclusions can be drawn:

- Short-run pass-through is very low in the euro area for a wide range of prices. Similar to the United States, the impact of an exchange rate shock on factor and trade prices, and on wholesale and retail prices (excluding energy), is near zero.

- Pass-through tends to rise over time in the euro area, although the extent of wage and consumer price pass-through remains comparatively small. Pass-through in producer and export prices is somewhat higher, but the highest degree of pass-though (near unity) is in euro area import prices. The differences in relative pass-through in import prices and consumer prices suggest that the roles of the retail sector and local distribution costs are important for price determination.

- The pattern of pass-through in trade prices suggests a fair degree of asymmetry with respect to the pricing behavior of domestic and foreign firms operating in the euro area (and the United States). Specifically, the impulse-response patterns suggest a high degree of local currency pricing in import prices and producer currency pricing in export prices. For the United States and the euro area, this suggests that firms are pricing in dollars and euros, respectively. For Japan and smaller, more open economies, the behavior of pass-through is more consistent with firms operating significantly in foreign currencies.

- Local currency pricing and "pricing to market" behavior notwithstanding, expenditure switching effects still operate in these economies, although short-run trade elasticities can be small. Nevertheless, the model suggests that an exchange rate depreciation improves the trade balance, once both volume and pass-through effects are factored in. Given its generally small effects on the trade balance, however, the exchange rate adjustment required to achieve a moderate degree of external adjustment may, in some circumstances, be substantial in the absence of adjustment in other variables. 


\section{Unit Root and Stationarity Tests}

Test statistics based on Phillip-Perron's nonparametric unit root test and Kwiatowski et al. (KPSS) stationarity test are shown in Table 5. The alternative hypothesis with the Phillips-Perron test and the null hypothesis with the KPSS test is trend stationarity. The tests suggest that the levels (first-differences) of these variables are nonstationary (stationary). The borderline cases where the tests give conflicting answers are CPI inflation-where the tests reject a unit root and stationarity, respectively-and import price inflation-where tests fail to reject a unit root and stationarity, respectively.

Table 5. Unit Root and Stationarity Tests

(Euro Area monthly data, 1990-2002)

\begin{tabular}{lccc}
\hline Variable & Phillips-Perron $Z_{\mathrm{t}}$ Test & KPSS $\eta_{\tau}$ Test & Order of Integration \\
\hline Neer & -2.34 & $0.34^{* *}$ & $\mathrm{I}(1)$ \\
$\Delta$ Neer & $-8.46^{* *}$ & 0.07 & $\mathrm{I}(0)$ \\
Cpi & -2.89 & $0.74^{* *}$ & $\mathrm{I}(1)$ \\
$\Delta$ Cpi & $-10.87^{* *}$ & $0.36^{* *}$ & $\mathrm{I}(0)$ or I $(1)$ \\
Ppi & -1.66 & $0.32^{* *}$ & $\mathrm{I}(1)$ \\
$\Delta$ Ppi & $-5.86^{* *}$ & 0.09 & $\mathrm{I}(0)$ \\
Px & -0.92 & $0.27^{* *}$ & $\mathrm{I}(1)$ \\
$\Delta$ Px & $-3.29 *$ & 0.10 & $\mathrm{I}(0)$ \\
Pm & -2.38 & $0.15^{* *}$ & $\mathrm{I}(1)$ \\
$\Delta$ Pm & -2.61 & 0.11 & $\mathrm{I}(0)$ or $\mathrm{I}(1)$ \\
Wage & -2.46 & $0.63^{* *}$ & $\mathrm{I}(1)$ \\
$\Delta$ Wage & $-6.56^{* *}$ & 0.07 & $\mathrm{I}(0)$ \\
\hline
\end{tabular}

An $*(* *)$ indicates significance at the 10 (5) percent level.

Phillips-Perron unit root test includes deterministic time trend under the alternative.

Kwiatowski et al. (1992) stationarity test includes deterministic time trend under the null.

\section{Cointegration Tests}

Given that the unit root and stationarity tests suggest that the log levels of the exchange rate and various price measures are nonstationary, cointegration tests are conducted to examine whether a linear combination of these variables is stationary. Table 6 reports the results of Phillips-Ouliaris residual-based test for cointegration with window size $=2$. Other window sizes produce similar results. The tests fail to reject the null of no cointegration.

Table 6. Cointegration Tests

(Euro Area monthly data, 1990-2002)

\begin{tabular}{lcc}
\hline No. of Regressors & $\hat{P}_{z}$ Test (demeaned) & $\hat{P}_{z}$ Test (demeaned \& detrended) \\
\hline $\mathrm{n}=5$ & 115.10 & 120.43 \\
& $(225.23)$ & $(284.01)$ \\
\hline
\end{tabular}

Notes: Multivariate trace statistic based on Phillips and Ouliaris (1990); 10 percent critical value given in parentheses. 


\section{Granger Causality Tests}

Granger causality tests were conducted to examine if (changes in) euro area exchange rates and prices have predictive content for each other. Simple bivariate tests indicate that the nominal effective exchange rate Granger-causes (i.e., helps predict) several price measures, but prices fail to Granger-cause exchange rates. The exchange rate is found to be a significant predictor for trade prices and has predictive content for wages at shorter lag length.

Table 7. Bivariate Granger Causality Tests

(Euro Area monthly data, 1990-2002)

\begin{tabular}{lcccc}
\hline Price Measure & Lags & $\begin{array}{c}\mathrm{H}_{0} \text { : Exchange rate does not } \\
\text { cause price measure }\end{array}$ & Lags & $\begin{array}{c}H_{0}: \text { Price measure does } \\
\text { not cause exchange rate }\end{array}$ \\
\hline Cpi & 12 & 0.66 & 2 & 0.96 \\
Ppi & 14 & 0.99 & 2 & 0.87 \\
Px & 13 & 0.06 & 2 & 0.27 \\
Pm & 13 & 0.00 & 2 & 0.70 \\
Wage $^{1}$ & 14 & 0.54 & 2 & 0.47 \\
\end{tabular}

Note: Reported numbers are $p$-values on the relevant exclusion restriction ( $F$-test).

Lag length selection based on Akaike Information Criterion.

${ }^{1}$ At one lag, the exchange rate Granger-causes wages $(p=0.04)$.

\section{Block Exogeneity Tests}

To generalize Granger causality tests to a multivariate context, consider the following partitioned $\operatorname{VAR}(p)$ system:

$$
\begin{aligned}
& \Delta s_{t}=c_{1}+\mathrm{A}_{1} X_{1 t}+\mathrm{A}_{2} X_{2 t}+\varepsilon_{1 t} \\
& \Delta P_{t}=c_{2}+\mathrm{B}_{1} X_{1 t}+\mathrm{B}_{2} X_{2 t}+\varepsilon_{2 t}
\end{aligned},
$$

where $c_{1}$ and $c_{2}$ represent a constant term and monthly time dummies, $P$ represents the $(5 \times 1)$ vector of price variables, $X_{1}$ and $X_{2}$ are ( $\left.p \times 1\right)$ and (5px1) vectors of lagged changes in exchange rates and prices, respectively, with conformable matrices of autoregressive coefficients $A_{1}, A_{2}, B_{1}$ and $B_{2}$. Block exogeneity test results are shown in Table 8 below.

Table 8. Block Exogeneity Tests

(Euro Area monthly data, 1990-2002)

\begin{tabular}{lcc}
\hline Lag Length & $\mathrm{H}_{0}: \mathrm{A}_{2}=0$ & $\mathrm{H}_{0}: \mathrm{B}_{1}=0$ \\
$\mathrm{p}=7$ & 32.42 & 50.48 \\
& $(0.59)$ & $(0.04)$
\end{tabular}

Notes: Test statistic is based on likelihood ratio test with degrees of freedom correction and is distributed as $\chi^{2}(5 p)$. Significance levels given in parentheses. 


\section{Sensitivity Analysis}

In the 6-variable VAR system, there are $6 !=720$ possible orderings under the Cholesky decomposition used to identify structural shocks. In general, when the reducedform residuals from the VAR do not display high cross correlations, the order of factorization makes little difference. ${ }^{43}$ Otherwise, the results can be sensitive to the choice of ordering. Since the focus here is solely on the effects of a shock to the exchange rate, orderings among the price variables--appearing before or after the exchange rate, respectively--do not matter. Thus, the relevant reorderings to consider surround the placement of the exchange rate and the combinations of price variables selected to appear either before or after the exchange rate given its order in the VAR. ${ }^{44}$

Changing the order of the exchange rate in the VAR, however, can be shown to have little impact on the results for the euro area. Compared to the case where the exchange rate appears first in the VAR, placing the exchange rate last in the VAR produces similar passthrough elasticities. See Table 9. Note that these results obtain despite the fact that the impulse-responses for the exchange rate itself differs across the two orderings, displaying less persistence in the latter case where the exchange rate shock depends recursively on the reduced-form residuals from all the price equations.

\footnotetext{
${ }^{43}$ From the variance-covariance matrix, the correlations between residuals are less than 0.2 with the notable exceptions of the exchange rate and trade prices and between trade prices themselves.

${ }^{44}$ This reduces the number of relevant reorderings considerably. The possible cases can be enumerated as follows: $\sum_{\mathrm{x}=0}^{5} 5 \mathrm{Cx}=32$, where $n \mathrm{C} r$ denotes the " $n$ choose $r$."
} 
Table 9. Euro Area Pass-Through Elasticities Across VAR Reorderings

\begin{tabular}{|c|c|c|c|c|}
\hline & $t=1$ & $t=6$ & $t=12$ & $t=18$ \\
\hline \multicolumn{5}{|c|}{ (Exchange Rate First in VAR) } \\
\hline Cpi & 0.00 & 0.01 & 0.02 & 0.02 \\
\hline Ppi & 0.00 & 0.04 & 0.11 & 0.17 \\
\hline Wage & -0.02 & 0.04 & 0.07 & 0.05 \\
\hline Px & 0.02 & 0.18 & 0.31 & 0.45 \\
\hline $\mathrm{Pm}$ & 0.03 & 0.42 & 0.81 & 1.17 \\
\hline \multicolumn{5}{|c|}{ (Exchange Rate Last in VAR) } \\
\hline Cpi & 0 & 0.02 & 0.02 & 0.03 \\
\hline Ppi & 0 & 0.05 & 0.11 & 0.18 \\
\hline Wage & 0 & 0.04 & 0.08 & 0.05 \\
\hline Px & 0 & 0.10 & 0.20 & 0.30 \\
\hline $\mathrm{Pm}$ & 0 & 0.30 & 0.63 & 0.97 \\
\hline
\end{tabular}

Notes: Entries report percent change in price measure divided by percent change in exchange rate in response to unit exchange rate shock from Cholesky decomposition of innovations.

As seen in the table, the implied pass-through elasticities from the two VARs are fairly similar. On impact, euro area prices are essentially predetermined in response to the exchange rate shock. It should be stressed, however, that the exchange rate shock has zero contemporaneous effect on prices (i.e., prices are fully predetermined) by construction in the latter VAR, based on the ordering of variables. In the case of the euro area (and the United States) this restriction appears valid empirically. Hence, the reordering makes little difference. For other industrial countries, however, this is generally not true for trade prices as shown by Table 2 and should not be imposed. So long as the exchange rate appears before trade prices in the VAR for these countries, alternative impulse-response functions will closely match those reported in the text. 


\section{References}

Anderton, Bob, 2003, "Extra-Euro Area Manufacturing Import Prices and Exchange Rate Pass-through,” ECB Working Paper No. 219, March (Frankfurt: European Central Bank).

Bergin, Paul, and Robert C. Feenstra, 2001, "Pricing-to-Market, Staggered Contracts, and Real Exchange Rate Persistence," Journal of International Economics, Vol. 54, pp. 333-359.

Bekx, Peter, 1998, "The Implications of the Introduction of the Euro for non-EU Countries," Euro Papers 26, European Commission, July (Brussels: European Commission).

Betts, Caroline, and Michael B. Devereux, 1996, "The Exchange Rate in a Model of Pricingto-Market," European Economic Review, Vol.40, pp. 1007-1021. , 2000, "Exchange Rate Dynamics in a Model of Pricing-to-Market," Journal of International Economics, Vol.50, pp. 215-244.

Burstein, Ariel T., Joao C. Neves, and Sergio Rebelo, 2003, "Distribution Costs and Real Exchange Rate Dynamics During Exchange-Rate-Based Stabilizations," Journal of Monetary Economics, Vol. 50, pp. 1189-1214.

Calvo, Guillermo, A., 1983, "Staggered Prices in a Utility-Maximizing Framework," Journal of Monetary Economics, Vol. 12, pp. 383-98.

Calvo, Guillermo A. and Carmen M. Rheinhart, 2002, "Fear of Floating," Quarterly Journal of Economics, Vol. 117, pp. 379-408.

Campa, Jose M., and Linda S. Goldberg, 2001, "Exchange Rate Pass-Through into Import Prices: A Macro or Micro Phenomenon?," manuscript, Federal Reserve Bank of New York (revised March 2002).

Choudhri, Ehsan U., and Dalia S. Hakura, 2001, "Exchange Rate Pass-Through to CPI: Does the Inflationary Environment Matter?," IMF Working Paper 01/194 (Washington: International Monetary Fund).

Choudhri, Ehsan U., Hamid Faruqee, and Dalia S. Hakura, 2002, "Explaining the Exchange Rate Pass-Through in Different Prices," IMF Working Paper 02/224 (Washington: International Monetary Fund).

Corsetti, Giancarlo, and Luca Dedola, 2002, "Macroeconomics of International Price Discrimination,” ECB Working Paper No. 176, September (Frankfurt: European Central Bank). 
Devereux, Michael, Charles Engel, and Cedric Tille, 1999, "Exchange Rate Pass-Through and the Welfare Effects of the Euro," forthcoming, International Economic Review and NBER Working Paper No. 7382.

Devereux, Michael, and Charles Engel, 2002, "Exchange Rate Pass-Through, Exchange Rate Volatility, and Exchange Rate Disconnect," Journal of Monetary Economics, Vol. 49, pp. 913-940.

— 2000, "Monetary Policy in the Open Economy Revisited: Price Setting and Exchange Rate Flexibility," NBER Working Paper 7665.

Dominguez, Kathryn, 1999, "The Role of the Yen," in International Capital Flows, ed. by Martin Feldstein, pp. 133-171, (Chicago: University of Chicago Press for the NBER).

Engel, Charles, 2002, "Expenditure Switching and Exchange Rate Policy," NBER Macroeconomics Annual Report.

Faruqee, Hamid, 1995,"Pricing to Market and the Real Exchange Rate," IMF Staff Papers, December (Washington: International Monetary Fund).

_ 2003,"Exchange Rate Pass-Through and External Adjustment in the Euro Area," IMF Country Report 03/298, August.

Flath , David, 2003, "Regulation, Distribution Efficiency, and Retail Density," NBER Working Paper 9450, January.

Flood, Robert A., and Andrew K. Rose, 1995, "Fixing Exchange Rates, A Virtual Quest for Fundamentals," Journal of Monetary Economics, Vol. 36, pp. 3-37.

Friedman, Milton, 1953, "The Case for Flexible Exchange Rates," in Essays in Positive Economics, pp. 157-203, (Chicago: University of Chicago Press).

Gagnon, Joseph and Jane Ihrig, 2002,"Monetary Policy and Exchange Rate Pass-Through," Board of Governors of the Federal Reserve System, International Finance Discussion Papers No. 704 (July).

Giovannini, Alberto, 1988, "Exchange Rates and Traded Goods Prices," Journal of International Economics, Vol. 24, No. 1-2, pp. 45-68.

Goldberg, P., and M. Knetter, 1997, "Goods Prices and Exchange Rates: What Have We Learned?," Journal of Economic Literature, Vol. XXXV, pp. 1243-1272, September.

Hahn, Elke, 2003, "Pass-through of External Shocks to Euro Area Inflation,” ECB Working Paper No. 243, March (Frankfurt: European Central Bank). 
Hamilton, James D., 1994 Time Series Analysis (Princeton, New Jersey: Princeton University Press).

Herzberg, Valerie, George Kapetanios, and Simon Price, 2003, "Import Prices and Exchange Rate Pass-through: Theory and Evidence from the United Kingdom," Bank of England Working Paper No. 182.

Hufner, Felix P., and Michael Schroder, 2001, “Exchange Rate Pass-Through to Consumer Prices: A European Perspective,” Discussion Paper 02-20, Center for European Research.

Hunt, Benjamin, and Alessandro Rebucci, 2003, "The U.S. Dollar and the Trade Deficit: What Accounts for the Late 1990s," IMF Working Paper WP/03/194.

Isard, Peter, Hamid Faruqee, G. Russell Kincaid, and Martin Fetherston, 2001, "Methodology for Current Account and Exchange Rate Assessments," IMF Occasional Paper 209 (Washington D.C.: International Monetary Fund).

Jaeger, Albert, 2002, "Euro Area Trade Flows and the Exchange Rate: How Much Disconnect?," IMF Country Report 02/236.

Jeanne, Olivier, and Andrew K. Rose, 2002, "Noise Trading and Exchange Rate Regimes," Quarterly Journal of Economics, Vol. 117, pp. 537-69.

Kasa, Kenneth, 1992, "Adjustment Costs and Pricing-to-Market: Theory and Evidence," Journal of International Economics, Vo. 32, No. 1-2, pp. 1-30, February.

Kieler, Mads, 2001, "Tracking the Pass-through of External Shocks to Euro Area Inflation," IMF Country Report 01/201.

Kwiatowski, Phillips, Schmidt and Shin, 1992, "Testing the Null Hypothesis of Stationarity Against the Alternative of A Unit Root: How Sure Are We That Economic Time Series Have a Unit Root?," Journal of Econometrics, Vol. 54, pp. 159-178.

Kollmann, Robert, 2001, "The Exchange Rate in a Dynamic-Optimizing Business Cycle Model With Nominal Rigidities: A Quantitative Investigation," Journal of International Economics, Vol. 55, pp. 243-262.

Krugman, Paul, 1987, "Pricing to Market When the Exchange Rate Changes," in RealFinancial Linkages Among Open Economics. ed. by Sven W. Arndt and J. David Richardson, pp. 49-70 (Cambridge, Massachusetts: MIT Press). , 1989, Exchange Rate Instability (Cambridge, Massachusetts: MIT Press).

Lane, Philip, 2001, "The New Open Economy Macroeconomics: A Survey," Journal of International Economics, August. 
Marston, Richard, 1990, "Pricing to Market in Japanese Manufacturing," Journal of International Economics, Vol. 29, pp. 217-236.

McCarthy, Jonathan, 2000, "Pass-Through of Exchange Rates and Import Prices to Domestic Inflation in Some Industrialized Economies," manuscript, Federal Reserve Bank of New York, August.

Mussa, Michael, 1984, "The Theory of Exchange Rate Determination," in Exchange Rate Theory and Practice. ed. by John F.O. Bilson and Richard C. Marston, pp. 13-78 (Chicago, Illinois: University of Chicago Press).

Obstfeld, Maurice, 2002, "Exchange Rates and Adjustment: Perspectives from the New Open Economy Macroeconomics," NBER Working Paper No. 9118.

Obstfeld, Maurice, and Kenneth Rogoff, 1995, “Exchange Rate Dynamics Redux," Journal of Political Economy, Vol.103, pp. 624-660. , 2000a, “ New Directions for Stochastic Open Economy Models," Journal of International Economics, Vol. 50, pp.117-153. , 2000b, "The Six Major Puzzles in International Macroeconomics: Is There a Common Cause?" NBER Working Paper No. 7777.

Peersman, Gert, and Frank Smets, 2002, "The Monetary Transmission Mechanism in the Euro Area: More Evidence from VAR Analysis," ECB Working Paper No. 91, December (Frankfurt: European Central Bank).

Phillips, Peter, and Sam Ouliaris, 1990, "Asymptotic Properties of Residual Based Tests for Cointegration," Econometrica, Vol. 58, pp. 165-193.

Smets, Frank, and Raf Wouters, 2002, “Openness, Imperfect Exchange Rate Pass-Through and Monetary Policy," Journal of Monetary Economics, Vol. 49, pp. 947-81.

Yang, J. 1997, "Exchange Rate Pass-Through in US Manufacturing Industries," Review of Economics and Statistics, Vol. LXXIX, No.1, February. 